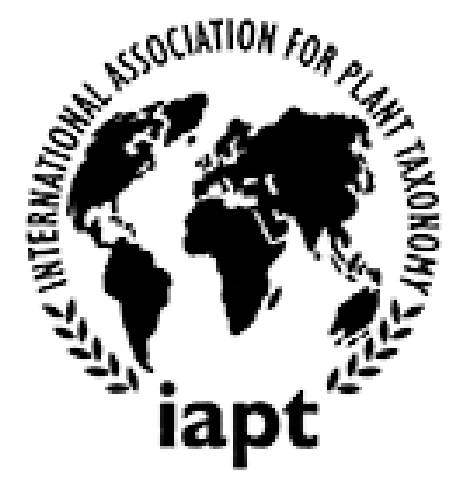

The Typification of Cuphea (Lythraceae): C. viscosissima versus C. decandra Author(s): Julià Molero and Gea Zijlstra

Source: Taxon, Vol. 48, No. 4 (Nov., 1999), pp. 797-799

Published by: International Association for Plant Taxonomy (IAPT)

Stable URL: http://www.jstor.org/stable/1223651

Accessed: 12/02/2015 11:27

Your use of the JSTOR archive indicates your acceptance of the Terms \& Conditions of Use, available at http://www.jstor.org/page/info/about/policies/terms.jsp

JSTOR is a not-for-profit service that helps scholars, researchers, and students discover, use, and build upon a wide range of content in a trusted digital archive. We use information technology and tools to increase productivity and facilitate new forms of scholarship. For more information about JSTOR, please contact support@jstor.org. 


\title{
The typification of Cuphea (Lythraceae): C. viscosissima versus C. decandra
}

\author{
Julià Molero $^{1} \&$ Gea Zijlstra ${ }^{2}$
}

\begin{abstract}
Summary
Molero, J. \& Zijlstra, G.: The typification of Cuphea (Lythraceae): C. viscosissima versus C. decandra. - Taxon 48: 797-799. 1999. - ISSN 0040-0262.

The nomenclatural type of the name Cuphea was stated by Graham to be $C$. decandra, but there is an earlier type designation by Swart who chose $C$. viscosissima. Both options are discussed, and it is concluded that Swart's typification must stand. A lectotype of $C$. viscosissima is designated, superseding the neotype proposed by Graham.
\end{abstract}

While the Lythraceae treatment for the Flora of Paraguay was being prepared (A. Duré \& J. Molero, unpubl.), a problem arose over the typification of the generic name Cuphea. The type mentioned in $I N G$ (Farr \& al., 1979) does not coincide with that designated by Graham (1968). It is important to resolve this contradiction in order to establish the correct nomenclature below the level of genus.

The choice of the nomenclatural type of Cuphea is no simple matter, because Browne (1756) did not use binomials and hence there is no explicit reference to a species name. According to Graham (1968), the genus was described on the basis of a single species and probably a single collection, of which no material has been found. Graham related the vicissitudes of the generic name and, after a welldocumented study of the 5 species of Cuphea now present in Jamaica, concluded that the one that most closely matches Browne's protologue is $C$. decandra Aiton (C. ciliata (Sw.) Koehne, non Ruiz \& Pav.). She accordingly designated $C$. decan$d r a$ as the type of the generic name.

This choice is in contradiction with the type mentioned for Cuphea in Farr \& al. (1979), C. viscosissima Jacq. This type is maintained in NCU-3 (Greuter \& al., 1993). Prior to the publication of $I N G$ in 1979, its records were issued on printed cards distributed among others to a considerable number of libraries. The card on Cuphea, on which ING collaborator J. J. Swart cited C. viscosissima as the nomenclatural type, was issued in June 1965. Swart's designation antedates Graham's, even though the latter author failed to refer to it in her papers (Graham. 1.c.; 1988: 40; and 1998: 30).

The Tokyo Code (Greuter \& al., 1995: Art. 10, Ex. 2) mentions an example of effective type designation on a printed ING card, by the same Swart. His choice, being the earliest one, cannot be dismissed, even though Swart himself might have thought that Cuphea viscosissima automatically provides the type because it is the earliest binomial published in Cuphea. C. viscosissima is distributed throughout the southeastern United States. According to Graham (l.c.) it is believed to have been introduced to Jamaica after Browne's visit to the island, but this is hard to prove.

Not having found any original material of Cuphea viscosissima, Graham (1988: 138) designated a neotype (a specimen in $\mathrm{MICH}$ ). This choice contravenes Art. 9.2 of the Code, since original material from which a lectotype can be chosen does exist: the plate (t. 177) that accompanies the protologue. Moreover, a sheet from the Jac-

\footnotetext{
'Laboratori de Botànica, Facultat de Farmàcia, Universitat de Barcelona, E-08024 Barcelona, Spain.

${ }^{2}$ Herbarium, Heidelberglaan 2, NL-3584 CS Utrecht, Netherlands.
} 
quin herbarium, conserved in Vienna (W) in a type folder, must be considered. This specimen contains three plants, complete with flower and fruit, in a perfect state of conservation, which can be attributed with confidence to $C$. viscosissima. The sheet is labelled "Lytrum Cuphea" by the younger Jacquin in the lower left-hand corner. A label in the bottom right-hand corner has " $C$. viscosissima Jacq." (in Koehne's writing), "Lythrum Cuphea", "Hb. Jacq.", and "Hort. bot. Vind." (in unknown hands). We do not know the date at which these plants, cultivated in the Vienna Botanical Garden, came into Jacquin's herbarium. Rechinger (in D'Arcy, 1970) suggested that specimens annotated by the younger Jacquin and bearing the inscription "Hb. Jacqu. Hort. bot. Vind." are acceptable as lectotypes.

We have compared the original plate of Cuphea viscosissima with the plants from the Jacquin herbarium. The plate shows a somewhat younger and more fully developed individual than those in the herbarium; it closely resembles the plant on the left-hand side of the sheet, but is not exactly the same. At that period it was usual when drawing to make slight alterations to the model, which was usually a freshly cut fragment or, as in this case, an entire plant. The plants on the sheet do not seem to have been used directly for the illustration of $C$. viscosissima but very likely they belonged to the same accession cultivated in the Vienna Botanical Garden. In view of the impossibility to prove beyond doubt that the specimen is part of the original material, we prefer to designate the original illustration as lectotype.

Cuphea viscosissima Jacq., Hort. Bot. Vindob. 2: 83. 1772-1773. - Lectotype (designated here): [icon] "Cuphea viscosissima Jacq." in Jacquin, Hort. Bot. Vindob. 2: t. 177. 1772-1773. - Epitype (designated here): "Lythrum Cuphea, Hb. Jacq., Hort. bot. Vind." (W).

Back to typification of the generic name: maintaining Swart's choice will keep substantially intact the nomenclature of the subgenera proposed by Koehne (1903) in the, so far, most complete monograph of the genus. Cuphea viscosissima is placed in C. subg. Cuphea (=C. subg. Bracteolatae Graham, 1988: 42). The section containing $C$. viscosissima ( $C$. sect. Heterodon Koehne) will become $C$. sect. Cuphea.

One problem to be considered is that $C$ uphea viscosissima does not entirely match Browne's original description. Neither does $C$. decandra. Both species have a calyx with six lobes and corolla with six petals, whereas the protologue states "periantium ... tubus ... ad faucem ... quinque crenatus" and "corolla pentapetala". Graham does not mention the number of calyx lobes and explains Browne's inaccuracy over petal number by the ease with which the petals of some species are shed. As there are no pentamerous flowers in Cuphea, Browne must indeed have erred; but also, there can be no "available element that is not in conflict with the protologue" that would permit to supersede Swart's choice under Art. 10.5(b) of the Code.

Comparing the two propsoed types, Cuphea viscosissima presents a viscousglandular perianth (Browne writes "periantium ... villosus") and flowers in a leafy raceme (the protologue mentions "floribus spicatis terminalibus"). In $C$. decandra the perianth is not villous and the inflorescence is not a spike but a raceme (Koehne, 1903: 110), the flowers being borne on short pedicels measuring 2-5(-7) mm. As neither species is in full agreement with the protologue, we consider it justified to retain Swart's choice. Since Browne's protologue of Cuphea does not include any (reference to a) species name, this choice, by analogy, has a status similar to a neotype designation, even though "neotype" and similar terms cannot be used at generic 
rank (Code: Art. 10. Note 1). Such status is expressed in the Code (Art. 10.2) by the proviso: "the choice is to be superseded if it can be demonstrated that the selected type is not conspecific with any of the material associated with the protologue".

As we have explained, we do not believe that such a demonstration is possible. We thus reject Graham's typification (which has similar status but is later) and accept the type designation by Swart, as follows:

Cuphea P. Browne, Civ. Nat. Hist. Jamaica: 216. 10 Mar 1756. - Type (designated by Swart on ING card No. 20706. Jun 1965): C. viscosissima Jacq.

\section{Acknowledgement}

We are grateful to Dr E. Vitek for providing information and some suggestions on the Cuphea viscosissima specimen from the Jacquin herbarium (W).

\section{Literature cited}

Browne, P. 1756. The civil and natural history of Jamaica. London.

$\rightarrow$ D'Arcy, W. G. 1970. Jacquin names, some notes on their typification. Taxon 19: 554-560.

Farr, E. R., Leussink, J. A. \& Stafleu, F. A. (ed.), 1979. Index nominum genericorum (plantarum). Regnum Veg. 100-102.

$\rightarrow$ Graham, S. A. 1968. History and typification of the generic name Cuphea. Taxon 17: 534-536.

- 1988. Revision of Cuphea section Heterodon (Lythraceae). Syst. Bot. Monogr. 20.

Greuter, W., Barrie, F. R., Burdet, H. M., Chaloner, W. G., Demoulin, V., Hawksworth, D. L., Jørgensen, P. M., Nicolson, D. H., Silva, P. C., Trehane, P. \& McNeill, J. 1994. International code of botanical nomenclature (Tokyo Code) adopted by the Fifteenth International Botanical Congress, Yokohama, August-September 1993. Regnum Veg. 131.

- , Brummitt, R. K., Farr, E., Kilian, N., Kirk, P. M. \& Silva, P. C. 1993. NCU-3. Names in current use for extant plant genera. Regnum Veg. 129.

Koehne, E. 1903. Lythraceae. In Engler, A. (ed.), Das Pflanzenreich, 17. Leipzig. 